\title{
THREE FAMOUS LEGAL HOAXES
}

\author{
The Tichborne Case; \\ The Dreyfus Affoir; \\ The Alleged Conspiracy To Assassinate President Kennedy. \\ PROFESSOR ARTHUR L. GOODHART* \\ Mark Lane and Epstein have attracted considerable public support in their \\ attacks on the Warren Commission. In this article Professor Goodhart \\ refutes their evidence and compares them with similar hoaxes of the \\ past.
}

There is an often-quoted Latin tag which reads Quod homines credere volunt, id facile credunt (what men wish to believe they easily believe). In his book on The Tichborne Case Lord Maugham, later Lord Chancellor, cited this to explain what he said were "beyond doubt the most celebrated and perhaps the most interesting English trials of the last one hundred years." This is equally true when applied to the Dreyfus Affair, and to the conspiracy stories of the Kennedy assassination written by Mark Lane and Edward Epstein.

These are described as three famous hoaxes because in each of them a few dishonest men succeeded in persuading a large number of people to accept stories which are unsupported by any credible evidence. People believed because they wanted to believe. The cases are English, French and American which shows that human nature tends to be the same wherever we may find it. As is fitting, the American hoax is the greatest.

\section{The Tichborne Case}

One hundred years ago on June 27,1867 , the two Tichborne trials began; they finished seven years later in 1874 when the claimant to the Tichborne title and estates was found guilty of perjury and sent to prison for 14 years, and his lawyer, Dr. Kenealy, was disbarred. There were in fact two cases: the civil one which lasted 101 days in court, and the criminal prosecution which occupied 122 days.

The Tichborne family was one of the oldest Roman Catholic families in Great Britain, its history going back a thousand years. In 1827 James, the youngest of the four sons of Sir Edward Tichborne, married Henriette Felicite, a member of the Bourbon Conti family. It was general knowledge that she was the natural daughter of Mr. Henry Seymour, a wealthy Englishman, but this was never openly recognized. Perhaps this instilled in her a hatred of everything English.

Two years after the marriage, Roger Tichborne was born in Paris where his parents lived. Sixteen years later his father James inherited the title owing to a series of sudden deaths. He decided that his son must be brought up as an Englishman so, against his wife's opposition, he brought him to England and entered him at Stonyhurst, the famous 
Jesuit Seminary in the north of England. There Roger learned the elements of Latin, Greek and some algebra. As French was his native language, he had some difficulty with the construction of his sentences.

In 1848 he left school, being gazetted to the Sixth Dragoon Guards, the Carabineers', a cavalry regiment. He joined his regiment in Dublin in 1849, and was stationed in Ireland until 1852 . When the regiment received orders to leave for India, he sent in his papers and left the army.

While he was in the army, he spent some of his holidays with his uncle and aunt, Sir Edward and Lady Tichborne at their Tichborne estate. He fell in love with their daughter Kate, but there were serious drawbacks to their marriage as they were first cousins, and Roman Catholic cousins are not allowed to marry without Papal dispensation. Moreover Kate's mother, who was very strict, thought that Roger smoked and drank too much, and she disapproved of his reading the novels of Paul de Kock. Sir Edward told him that he would never sanction the marriage, but later he relented, insisting, however, that for three years there should be no engagement until Roger returned from his travels abroad. When Roger met Kate for the last time on 22 June, 1852, he gave her a paper saying that if they married he promised to build a church or chapel at Tichborne.

After visiting his parents in Paris, Roger sailed in March, 1853, from Havre to Chile. Later he crossed the mountains to Buenos Aires and finally to Rio. He then decided to visit Jamaica, and in April he sailed from Rio on an English ship, the Bella, for Kingston. Four days thereafter its long-boat was found at sea floating bottom upwards, but there was no sign of any survivors. Apparently all the passengers and members of the crew had been drowned. Not one of them has ever been heard of since. The insurance money on the ship was duly paid, and in July 1855 Roger's will was proved by his executors. In the previous year Kate had married Mr. Percival Radcliffe who later inherited a baronetcy.

Sir James Tichborne died in 1862, so that, Alfred, Roger's younger brother, who had married the previous year, succeeded to the title. A few months after his death in 1866, a posthumous son was born to his widow. He was now the heir.

For ten years no one doubted that Roger had been drowned when the Bella disappeared, except his mother, the dowager Lady Tichborne, who was convinced that he would return some day. She began advertising in many newspapers both in England and abroad, and in May 1865 she wrote to a Mr. Cubitt who maintained a "missing friends" office in Sydney, New South Wales to ask him to make further inquiries. At that time it was not unusual for younger sons who had got into difficulties in England to emigrate to Australia, and efforts might later be made to trace them. Cubitt then advertised in various Australian newspapers asking for information concerning Sir Roger Tichborne who, the advertisement said, had been a passenger on the Bella and was thought to have been rescued by a ship sailing for Australia. Shortly thereafter William Gibbes, an attorney in Wagga Wagga, wrote to Cubitt saying that he thought that he had spotted Sir Roger. A man calling himself Tomas Castro, but obviously an 
Englishman, had been his client when his butcher's shop failed. Thereafter he told him that Castro was an assumed name, and that he was heir to an English title. (As the whole point in the case that follows was whether Castro was Roger Tichborne, it is convenient to describe him as the claimant.)

The claimant, with the assistance of Gibbes, then wrote to Lady Tichborne apologizing for not having written to her in so many years, but saying that he would explain it when he returned. He asked her to send him $£ 200$. I believe that at that time this was all he hoped to get. Before receiving an answer from her he went to Sydney to see Cubitt. In one of her letters Lady Tichborne had referred to a negro, "'Old Bogle," who had been in Sir Edward Tichborne's service but was now in Sydney. When the Australian newspapers reported that "Sir Roger" had been found, Bogle went to the hotel in which they said that he was staying. The claimant was out so he waited for him in the courtyard. When the latter returned, he said to the elderly negro, "Hello, Bogle, is that you?" This was not a difficult feat as there were very few negroes in Australia and the claimant had been told that Bogle had a mop of white hair. They then had a long conversation which went so well that the claimant immediately invited Bogle to come back to England with him. This was crucial because it was from Bogle that the claimant learned most of his facts.

The claimant remained in Sydney for three months while he attempted to raise money. He continued his correspondence with Lady Tichborne and in one letter asked her whether she did not remember a birthmark on his left side. Her comment on this was, "My poor Roger confuses everything in his head, just as in a dream, and I believe him to be my son though his statements differ from mine." She urged him to return as soon as possible, but he did not get to London until Christmas Day, 1866. Two days later he drove to the Swan Inn, a few miles from Tichborne. The landlord was Edward Rous, who had been for over twenty years chief clerk to the solicitors who represented the Tichborne family. That evening they had a long talk which convinced Rous that the claimant was the missing heir by the extensive family knowledge that he had.

It was not until January 10 that the claimant crossed over to France to meet Lady Tichborne. This was the crucial visit. He was accompanied by a Mr. Leete whom he had met by chance in a billiard room, and the latter's solicitor Mr. John Holmes. They spent the night at a Paris hotel, but in the morning the claimant said that he was so ill that he could not go to see Lady Tichborne. Holmes and Leete then called on her begging her to come to the hotel. She was taken into the bedroom where the blinds were half drawn. The claimant was lying on the bed with his face turned to the wall. She bent over him and kissed him saying. "He looks like his father, and his ears are like his uncle's." At the end of the visit, she arranged to transfer to him $£ 1000$ a year until he had recovered the estate. This was all-important because people said that a mother must be able to recognize her own son. This was repeated again and again: a mother cannot mistake her own son.

Although Roger had spent the first sixteen years of his life in 
France, it did not surprise Lady Tichborne that the claimant did not remember a word of that language nor any mathematics or any Latin. She accepted his explanation that the shock of the ship-wreck had greatly affected his memory. She arranged for him to meet $M$. Chatillon, Roger's former tutor, but when he said to her "This is not your son", the only result was that she asked $M$. Chatillon to leave.

When the claimant returned to England, he took a house near London. The next six months were busy ones because he was collecting affidavits just as Mark Lane has collected affidavits to make his evidence look respectable. He was successful in getting the support of $\mathrm{Mr}$. Hopkins, who had retired as solicitor to the Tichborne family, and of $\mathrm{Mr}$. Bulpett, the local banker. Neither of them had recognized him at first but they were convinced by his intimate knowledge of family affairs.

The claimant was particularly fortunate in being recognized by former members of his regiment. Colonel Norbury said that at first he did not recognize him but after an interview of three hours he was convinced, as the claimant referred to many things that only Roger could have known. Major Heywood remembered him when he told him about a practical joke that had been played on Roger. General Custance, after some hesitation, recognized the expression of his eyes and the way in which he wrinkled his forehead. After this case ended the phrase became popular that "He was so stupid that even his fellow Cavalry officers noticed it."

A former soldier servant of Roger's read in the newspaper about the claimant and wrote to him asking to be taken into his employment; another ex-soldier also came to stay at Croydon. They got into touch with all the old soldiers they could find, and soon they were successful in getting a remarkable number of them to identify the claimant. Their evidence was embodied in affidavits carefully drawn up by the solicitor Holmes and others.

There were, however, two remarkable gaps in the claimant's list of affidavits. There was not a single member of the Tichborne or Seymour families who had recognized him.

Even more remarkable was the claimant's failure to obtain a single affidavit from any teacher or student who had been at Stonyhurst during the years in which the claimant said that he had been there. It was suggested by his supporters that there was a Jesuit conspiracy to defeat his claims. Why the Jesuits should have acted in this way since the claimant was a Catholic was not clear; but who could tell what motives might affect the Jesuits? At that time there was so much talk of a Catholic revival that it was easy to appeal to the more rabid Protestants by inventing a Jesuit conspiracy.

On March 12, 1868, Lady Tichborne died suddenly of a heart attack in London. The claimant asserted his belief that Lady Tichborne had been poisoned. An inquest was held but there was not a shadow of evidence of this. Lady Tichborne's death was a severe blow to the claimant because the $£ 1000$ a year which he received from her came to an end. It was necessary for him to raise money in other ways which he did by the issue of Tichborne bonds promising that they would be 
repaid as soon as the estate had been recovered. There are no exact figures concerning the bonds that were sold, but the amount must have run into thousands of pounds.

After interminable legal delays the civil case finally began on 10 May, 1871 with the reading of affidavits, followed by dreary evidence concerning the claimant's identity which occupied most of the 5213 printed pages of the report. There were, however, two occasions of special interest when the claimant made fatal errors.

During the preliminary proceedings it became known that before leaving England Roger Tichborne had handed a confidential packet to his friend Vincent Gosford who was then steward of the Tichborne estate. When Gosford gave evidence that he had destroyed the packet this relieved the claimant of the risk that he might be asked what instructions it contained. He then told his friends that the letter had contained a statement that he had seduced his cousin Kate, that he had refused to marry her, but that if it should be found that she was enceinte after he left England then Gosford should arrange to look after her. This incredible statement was completely untrue but the claimant seems to have thought that the family would make every effort to suppress it because in the Victorian period even a hint of scandal might gravely injure a woman. Kate was not, however, cowed by blackmail, and she later gave evidence that the claimant had lied.

The second error was due to the claimant's reference to one Arthur Orton who, he said. had worked on a cattle station in Australia with him and had been charged with stealing a horse. By extraordinarily skilful detective work the defense was able to prove that the claimant was, in fact. Arthur Orton, the son of a Wapping butcher. He had sailed to South America in 1848. returned to England in 1851. then went to Tasmania in 1852, and finally reached Australia in 1855 where he took the name of Tomas Castro probably to conceal some of his earlier escapades.

After seven years of litigation and at a cost of $\$ 500,000$ to the defendants the Tichborne case finally came to an end with evidence that occupied only a few hours. It was proved that Roger Tichbborne had been tatooed on his left arm; the claimant's arm was unmarked. The jury then announced that they had heard sufficient evidence.

At the conclusion of the case the Lord Chief Justice said that in his opinion the claimant had been guilty of wilful and corrupt perjury and directed him to be prosecuted on that charge. Strange to say many of the claimant's supporters remained faithful to him. Large sums were collected for his defense, and crowded public meetings were held throughout the country. It was all in vain because in the end the claimant was found guilty and sentenced to 14 years imprisonment. His counsel, Dr. Kenealy Q.C., who had behaved in an outrageous manner by insulting the judges and by making statements that he must have known were false, was disbarred by his Inn. This case showed how easily a clever plausible rogue can build up a false case and collect evidence that at first sight seems to be persuasive until it has been carefully analysed. 


\section{L'Affaire Dreyfus}

The Dreyfus Affair, which was really a series of trials, is one of the most famous in all legal history. It lasted from 1894 when the first charge was brought against Captain Dreyfus to his final rehabilitation in 1906.

Toward the end of the 19th century there was spy fever in many European countries as important developments were being made in the field of armaments. (The modern increase in espionage since the discovery of the atom bomb is not dissimilar.) The French, after their defeat in 1871, were particularly subject to this fear as there was always the threat that another war might break out. They established in Paris an Intelligence Service under the name of the Statistical Section which consisted of five officers who exercised important powers.

A Mme. Bastian served as a cleaning woman at the German embassy, but her primary function was to act as a spy for France in gathering any material that she could find there.

From time to time she collected the torn-up papers that the German military attache, Colonel Schwarzkoppen, threw into his wastepaper basket. Her most valuable find was a letter that had been torn across; it was written on flimsy paper and was unsigned. It set out a list of five matters on which information was being forwarded by the writer. The most important concerned the hydraulic brake on the new 120 field gun. There was also a note relating to Madagascar in which the French were particularly interested at that time. This letter became famous as the "bordereau" or schedule.

Suspicion fell on Captain Alfred Dreyfus who was one of the first Jewish officers to serve on the General Staff. He was an efficient officer, but he was not popular with his colleagues partly because of the growing wave of anti-Semitism that was sweeping over France, and partly because of his cold, reserved manner. The suspicion was based on two grounds. The first was that he was one of a very limited number of men who had had sufficient experience to deal with the five matters set out in the bordereau. Moreover he was known to have asked questions concerning them, and had often worked late at night. The second was that the handwriting of the bordereau was similar to his. When this was submitted to a number of experts, one of them, attached to the Bank of France, said that it was not his, but the others were convinced that it was. After some hesitation General Mercier, who was the Minister for War, decided that Dreyfus should be arrested. He was asked to confess his guilt and was shown a revolver with which he could "end the affair", but Dreyfus strenuously denied the charge.

A month later Dreyfus appeared before a military court which was held in private. The evidence produced by the prosecution was exceedingly weak, consisting almost entirely of the opinion of some of the experts that he had written the bordereau. There was no apparent motive for such a crime: Dreyfus was a wealthy man who had married a wealthy woman, and there was nothing to show that he was proGerman and anti-French. In these circumstances the prosecution took a step which was entirely illegal. Without advising Dreyfus or his 
counsel, it handed to the Court a secret dossier which contained some documents which could be interpreted as referring to the accused. The most important was a letter from the German military attache Colonel Schwarzkoppen to his Italian colleague which had been intercepted. It said, inter alia, that "Herewith twelve large-scale plans of Nice which that canaille de D. (scoundrel D.) has given me for you." It was assumed that the " $D$ " referred to "Dreyfus" although it was not clear whether the letter was a D or a $\mathrm{P}$. It was also suggested to the Court that there was more secret evidence that could not be disclosed without the risk of war. At the trial Commandant Henry, pointing to Dreyfus, cried, "The traitor, there he is." It is not surprising that in these circumstances the military court unanimously decided that Dreyfus was guilty and sentenced him to life imprisonment on Devil's Island.

Then General Mercier made a mistake because he decided that Dreyfus should be publicly degraded. On parade before a large assembly of troops and of the public in the Place Fonteney, his insignia of rank were torn from his uniform, and his sword was broken in two and thrown on the ground. As he was marched round the parade ground he shouted: "I am innocent. Vive la France!" Some people began to wonder then whether he really was guilty. However, that evening Captain Lebrun-Renaud, who had been in charge of Dreyfus in the parade, dined at Maxim's and told some friends that Dreyfus had confessed to him that he had supplied the German Embassy with documents. This alleged confession was reported in a number of newspapers, and in time it was accepted as proof of his guilt.

In July 1895 Colonel Sandherr, the head of the Statistical Section, had to resign owing to illness; it was rumored that he had been poisoned by a Jewish Syndicate that was said to have collected vast sums to help in freeing Dreyfus. He was succeeded by Colonel Picquart. He had shown no sympathy for Dreyfus, but he thought that there was more to discover in the case. Again Mme. Bastian, that indefatigable cleaning woman, played a leading role. She found in the waste-paper basket a letter-telegram called a petit bleu which had been torn into a number of pieces. It was addressed to Commandant Esterhazy and read: "II, therefore, request that you should let me have it in writing so that $I$ can decide whether I can continue my relations with the firm of $R$ or not." This cryptic message would suggest that Esterhazy was sending confidential information to the German embassy.

Picquart started inquiries concerning Esterhazy. They showed that he was a rather suspect character, always short of money, a gambler, and in continual pursuit of women. A specimen of Esterhazy's writing was compared with that of the bordereau and they seemed to be the same. Shortly thereafter Picquart was posted to Tunisia where the French were fighting but before he left he confided to his friend Leblois his suspicions.

In November, 1896, Commandant Henry showed to his commanding general a letter which he claimed had been found by Mme. Bastian. It purported to be a letter written by the Italian military attache to Schwartzkoppen in which he warned him that a question was to be asked in the Chamber of Deputies about Dreyfus, and that if new explanations 
were required Schwartzkoppen should deny that he had ever had relations with Dreyfus. If this letter was authentic then it was clear proof of Dreyfus's guilt. Finally to bring things to a head Mathieu Dreyfus wrote a letter to the Minister of War accusing Esterhazy of having written the bordereau. The Minister, who was convinced of Dreyfus's guilt, ordered a full court-martial of Esterhazy so as to establish his innocence. A month later the military judges unanimously found him not guilty. Then two days later Emile Zola the famous French novelist published in L'Aurore his historic article J'accuse. He accused various generals by name of having deliberately connived at an injustice. He challenged the government to prosecute him. It was a superb diatribe; each allegation was supported by proof, the arguments were logical, and the analysis of the motives was convincing. It was not composed of cowardly hints against unnamed persons.

The Government was forced to accept his challenge, by charging him with criminal libel. The Dreyfusards, as they were called, hoped that a civil court would be less prejudiced than the military ones had been, but in this they proved to be mistaken. Witnesses were allowed to express their own views concerning the guilt of the accused. Thus General Boisdeffre stated that there was a secret document proving Dreyfus's guilt. He said:

You, gentlemen of the jury, are the nation. If the nation has no confidence in the leaders of the army, in those responsible for national defense, then the leaders are ready to give up this heavy duty to others.

Faced with this threat, it took the jury only half an hour to find Zola guilty. He was sentenced to twelve months imprisonment and a fine of 3,000 francs. He escaped to England before being arrested.

Zola's conviction did not, however, stop those who believed in Dreyfus's innocence; it confirmed their belief that Esterhazy was being protected.

Then an extraordinary thing happened. To settle the Dreyfus affair once and for all the Minister for War had appointed Captain Cuignet to examine every document in the files. On August 13 he reported that when he had examined the letter which the Italian military attache was alleged to have written he found that the faint lines in the paper at the top and at the bottom of the letter were in one color while those in the middle were in another. The middle, which contained the reference to Dreyfus, was therefore a forged insertion. The Minister determined to interview Commandant Henry. After a long interrogation Henry confessed to being the author of the forgery. He was arrested, and sent to the military prison Mont Valerien. A few days later Henry cut his throat, and Esterhazy fled to Belgium.

For all practical purposes this ended the Affaire, but it was still necessary to dispose of the original charges against Dreyfus. He was brought back to France-a broken man-and a new military court was set up in Rennes. This time the prosecution placed great weight on the alleged confession made by Dreyfus to Captain Lebrun. More persuasive was the testimony given by General Mercier, who had been the Minister for War in 1894. He affirmed that he knew that Dreyfus was 
guilty, and that he had confessed three times. The officers, who constituted the Court, therefore had to decide between Mercier and Dreyfus. By a majority of 5 to 2 they decided that Dreyfus was guilty and condemned him to 10 years imprisonment. A week later President Loubet remitted the sentence. It was not, however, until 1906 that the Appeal Court formally declared that Dreyfus was innocent. At a public ceremony in a courtyard of the Ecole Militaire, he was decorated with the Legion of Honor. Colonel Picquart was present.

\section{The Assassination of President Kennedy}

The main facts relating to the assassination are so well known that it is only necessary to refer to them briefly. The Dealey Plaza is a large open square. At the north end is the seven-storey Texas School Book Depository Building. On the west side, flanked by Elm Street, is a grassy knoll rising sharply about $\mathbf{3 5}$ or $\mathbf{5 0}$ feet to a picket fence, about 4-1/2 feet high, behind which there is a large open space crossed by railroad tracks and used in part as a car park. On the south side there is a large overpass or bridge, used for railroad lines, and beneath which Elm Street and two other roads converge and pass. On the east side of the Plaza there are a number of high buildings at right angle to the Book Depository building so that any noises coming from it are funneled to the south. At 12:35 p.m. the President's car passed the Book Building, and then turned sharp left down Elm Street. After it had gone about 200 feet a number of shots rang out. The President was wounded by one bullet and killed by another one. Governor Connally, who was sitting on the jump seat immediately in front of the President, was wounded by a bullet that struck him in the back, exited from the front of his chest, struck his wrist and ended in his thigh. The President and the Governor were rushed to the Parkland Hospital where the President died. An hour later a man named Oswald was arrested in a cinema after attempting to shoot one of his captors. Two days later Oswald was killed by Jack Ruby while being transferred from one jail to another.

A week later President Johnson appointed a commission of investigation under the Chairmanship of Chief Justice Warren. Its function was similar to that of a Grand Jury. It was to make a Report or a Presentment in which it was to state who in its opinion was responsible for the assassination, who had wounded the Governor, and whether the press and the officials had acted properly. It was in no sense a trial court. If it had found that there was a fellow conspirator it would have been necessary for a Grand Jury to indict him by name before he could be tried in a regular court on a charge of murder. This procedure could not, of course, be followed in Oswald's case because he was dead.

When the Commission began its hearings Mark Lane, a New York lawyer, who had practiced law for 12 years from a storefront in East Harlem, demanded the right to appear as defense counsel for Oswald, having been appointed by Oswald's mother. The Commission refused on the ground that it was conducting an investigation and not a trial. It stated, however, that he could present to the Commission any relevant evidence that it ought to consider. He did so on two occasions. Of the 
552 witnesses who gave evidence he was the only one who asked for public hearings.

The basic conclusions in the Commission's Report were that (a) the shots which killed the President and wounded the Governor were fired from the sixth floor window at the south-east corner of the Book Depository building, that (b) there was no credible evidence that the shots were fired from any other location, and that (c) the shots were fired by Lee Harvey Oswald. Lane's book is 477 pages, but it can be judged by the first 40 . He disputes the first two conclusions on the ground that there was credible evidence that one or more shots were fired from the knoll, and that one or both of the shots that struck the President hit him from in front so that there must have been two assassins. Concerning Oswald's guilt he argues at great length that Oswald could not have shot so accurately, that the real assassin was someone else impersonating Oswald, that the rifle found in the building did not belong to Oswald. but if it did belong to Oswald it was planted there by the Dallas police. All the rest of the book dealing with Mrs. Odio, the fantastic story of Mrs. Perrin, the alleged meeting at the Carousel Club of Ruby. Tippit and Weissman, together with the suggested murder by the Dallas police of possible witnesses is used to create suspicion without a shred of evidence to support it. The technique is exactly that used in the Tichborne and the Dreyfus cases.

Lane is more precise when he says that "to conclude that 'no credible evidence' exists that shots came from any place other than the Book Depository is to ignore the evidence of Miss Mercer, Bowers, Price, Holland, Deputy Constable Weitzman and the railroad yardman who spoke with him." Later he adds James L. Simmons. Lane must have felt safe in assuming that hardly any of his American readers and none of his European ones would check his stories against the evidence that can be found in the 26 supplementary volumes published by the Commission.

Miss Mercer was one of a number of similar witnesses who after the assassination thought that they had seen someone carry what might have been a concealed rifle. A green truck which "looked like it had 1 or 2 wheels on the curb" of Elm Street blocked her way. She saw one of the two men in the truck "take out from the truck what appeared to be a gun-case," and then walk "up the grassy slope." When this incident occurred "there were three policemen standing talking near a motorcycle on the bridge just west of me." In her affidavit Miss Mercer did not state at what time this happened, so Lane has added the words "early in the day" when reporting what she said. This was a necessary guess because later in the morning Elm Street was patrolled by the police and there were people on the sidewalk who would have seen a man carrying a gun case which thereafter disappeared never to be found. The gunman must therefore have been hanging about for nearly four hours before the assassination took place, so in his recent interview in Playboy Lane changes the time by saying that it happened "Some time before the motorcade reached the area." Miss Mercer's reference to the three police officers she thought were on the bridge has been altered to read: "Dallas policemen were standing a short distance away, but they didn't move the.truck on." The point of Lane's comment was that this was 
evidence that the Dallas police were involved in the conspiracy, but it loses even this point if we realize that the police would have had to walk off the bridge, climb a picket fence, and then descend the knoll before reaching the truck. Lane's final comment is: "I have not been able to find her (Miss Mercer). She's no longer in Dallas." This must be the feeblest possible evidence on which to charge the Dallas police with complicity in the assassination.

The next witness, Lee Bowers, was a tower man operating the switches and signals controlling the movement of trains. He had an uninterrupted view of the area back of the picket fence from which Lane suggests that the shooting took place yet he never saw a man carrying a rifle or doing anything suspicious. He was, however, able to note that three cars which entered the area bore Goldwater campaign stickers, but the relevance of this is not apparent as it is not suggested that Senator Goldwater was involved in the assassination. When Bowers gave evidence before the Commission he stated that he first realized that there was "some unusual occurrence" because of something he "could not identify." He could not have seen anything that was happening on Elm Street which is $\mathbf{3 0}$ or $\mathbf{4 0}$ feet below the picket fence, so that it was probably the noise of people climbing the slope of which he was first aware. Lane's main point is that Bowers was prepared to tell more to the Commission if he had not been interrupted by $\mathrm{Mr}$. Ball who was questioning him. The record shows that $\mathrm{Mr}$. Ball repeatedly asked Bowers whether he had more to say so that there is not much substance in this point. However, when Bowers was interviewed by Lane himself two years later he said: "I was just going to tell that at the time the shots were fired, I looked at the fence and saw a puff of smoke, or flash of light, just when the shots were fired." This is astonishing because a puff of smoke and a flash of light can hardly be confused. Bowers was killed in an automoblie accident six months ago which Lane regards as suspicious, but Bowers could hardly have added anything to what he had already said.

The third witness was Mr. J. C. Price who was on the roof of the Terminal Annex Building across Dealey Plaza more than 150 yards from the picket fence. In his evidence to the Commission he said: "I saw one man run towards the passenger cars on the railroad siding after the volley of shots. . . He had something in his hand I couldn't be sure but it may have been a headpiece." When two years later he was interviewed and filmed by Lane his memory had improved. "He had on khaki trousers, a white shirt, and I think-I'm pretty sure that his hair was sandy and long. A man appearing about 145 pounds in weight and not too tall. I would say five six or seven. He was bare headed, and he was running very fast, which gave me the suspicion that he was doing the shooting, but I could be mistaken." The man "was carrying something in his right hand which could have been a gun." The meticulous precision of Price's second-thought evidence illustrates the legal maxim that an over-precise witness is usually telling a lie.

The fourth witness was G. M. Holland, who was accompanied by a lawyer when he gave his evidence, and then had to retire to bed. He was on the overpass when the shots rang out. He had "no doubt about 
seeing a puff of smoke come out from under those trees." He also saw a station wagon backed up toward the fence, and it looked as if "someone stood up on the bumper to see over the fence." It is astonishing that neither Bowers nor anyone else noticed this because a man standing on a bumper and holding a rifle can hardly have failed to attract more attention than a puff of smoke.

The fifth witness was Constable Weitzman. He said that he "ran in a northwest direction and scaled a fence towards where we thought the shots came from." He met a railroad employee who said he thought that "he had seen somebody throw something through a bush." Weitzmann himself was not impressed by this, and rushed over to the Book Building where he helped to find the assassination rifle.

Finally the reference to James L. Simmons is of special interest. He saw a motorcycle policeman drive up the grassy slope, jump off his motorcycle and then run up the rest of the hill. Simmons thought that he saw exhaust fumes of smoke. He said that in his opinion the shots came from the direction of the Texas Building.

This is the whole of Lane's so-called direct evidence that there was another assassin shooting from the knoll. An English critic has summed this up by saying: "The whole of Lane's book is nothing but a puff of smoke."

Lane also argues that the fact that ninety persons thought that the shots came from the knoll is convincing evidence that they came from there, but his own star witness Bowers testified that he could not distinguish between shots coming from the Book Building and from the overpass because "there is a reverberation which takes place from either location." Anyone who has been to the Grand Canyon or to St. Paul's Cathedral in London knows that if you clap your hands together you cannot distinguish between that and the echo which returns to you. Many of Lane's witnesses said that all the shots came from the knoll, but this is obviously impossible as it has never been questioned that Governor Connally was hit in the back. Even Lane has not been able to invent a story to answer that.

Lane's final point would seem to be a conclusive one. It is that as the wound in the front of the President's neck was an entrance wound, the bullet must have been fired either from the knoll or from the overpass. He says that: "Every doctor at Dallas' Parkland Hospital who examined the wound in President Kennedy's throat and made a statement to the press on the day of the assassination said the throat wound was an entrance wound. That means the bullet entered from the front." You can judge Lane's book by this because it is deliberately misleading. When the President was brought into the operating room he had only a few minutes to live. In a last desperate effort to keep him from choking to death Dr. Perry performed a tracheotomy operation,- - he cut a slit in the throat so that a tube could be inserted. Neither he nor any other doctor examined the wound to determine whether it was an entrance or an exit wound because that was the last thing that concerned them. It is, of course, impossible to prove what the exact words were that $\mathrm{Dr}$. Perry used when he was hurriedly interviewed by the press after he left the operating room, but he has repeated again and again that all 
that he could have said was that the wound might have been an entrance wound. Lane's suggestion,--because he does not dare to make a definite statement, - that all the doctors at the Parkland Hospital have been induced to alter their evidence is an attack on the good faith of the medical profession. Unfortunately the Parkland doctors cannot sue him for libel because the recent Supreme Court decision in The New York Times v. Sullivan requires the proof of malice. Mr. Considine has well said that Lane is "flying high on Kennedy's shroud" and Governor Connelly has called him a scavanger but unfortunately the desire to make money from a great, national tragedy does not constitute malice. The English law against such libels is far stricter: perhaps someone will test it some day.

\section{Epstein's Book}

Epstein's book has been praised as being "scholarly", but it is an unusual type of scholarship because most of his more important notes are misleading, and his quotations are untrue. In his attack on the members of the Commission he quotes verbatim from interviews he held with seven of the counsel in which they told him that the Commissioners "had no idea what was happening," "they did nothing", and that they were "nothing more than figureheads." It seems rather odd that lawyers should speak in these terms of a Commission for which they had worked. I made enquiries and I found that each of these quotations was repudiated as being false. Epstein had taken no written notes at the time, and he failed to check with the persons he had interviewed to see whether his quotations were accurate even when he had promised to do so.

What is worse is that throughout this book Epstein misquotes the evidence given by the witnesses so that his so-called conclusions of fact are invalid. This is true of the two basic statements on which his whole attack on the Report is founded.

His first statement is that "according to the established facts, it was physically impossible for the assassination rifle to have been fired twice during the time period when the President and Governor Connally were first wounded. Either both men were hit by the same bullet, or there were two assassins." As authority for this he quotes $\mathrm{Mr}$. Redlich, a counsel to the Commission, as follows: "To say that the President and the Governor were hit by separate bullets is synonymous with saying that there were two assassins." This would seem to be conclusive until we find that $\mathrm{Mr}$. Redlich has categorically repudiated that he ever said this. It is clear that Redlich preferred the one bullet theory, but this did not mean that he thought that the two bullet theory was " physically impossible." On this point Arnold Specter has said that "The events of the assassination just cannot be reduced to mathematical certainty by use of a stop watch."

The second "fact" as stated by Epstein was that "other evidence arose which showed that it was not possible that both men were hit by the same bullet." To support this he quoted from a supplemental Report made by the F.B.I. which said: "Medical examination of the President's body had revealed that the bullet which entered his back had penetrated 
to a distance of less than a finger length." This again would seem to be conclusive because if the bullet only penetrated three inches then it could not have gone on and struck the Governor. The only weakness of Epstein's "fact" is that it is completely untrue. Dr. Humes, who performed the autopsy, testified to the Commission that "We were able to ascertain with absolute certainty that the bullet had passed by the apical portion of the right lung producing the injury which we mentioned." From there the bullet exited from the front of the President's neck. To explain this conflict Epstein suggests that the three surgeons were persuaded for some unknown reason to give false evidence, but is it not more probable that the F.B.I. made a slip in its Report as the F.B.I. itself acknowledged?

Epstein concludes that as Oswald could not have fired the two bullets that hit the President and the Governor, and as a single bullet could not have hit both of them, there must have been a second assassin. This is a self-evident syllogism which even a moderately intelligent schoolboy would be able to understand. Why then did the Commissioners fail to recognize it? This, he says, was due to its "dominant purpose" to conceal the facts. It was telling a "political truth" in its Report: in plain English it was, according to him, telling a lie.

\section{Conclusion}

1. Lane has made great play, especially in Europe, of the fact that the majority of the American people probably believe that there was a conspiracy to assassinate the President, but such a Gallup poll cannot prove anything except that the people often believe nonsense. Thus in the Tichborne case the majority of the people in Great Britain believed for a time that the claimant was Sir Roger Tichborne, but no rational person would do so today. In France the overwhelming majority of the people believed for more than two years that Captain Dreyfus sold secret documents to Germany but there are only a few political fanatics who do so today. I am certain that in a short time most people will wonder why they ever believed in the Lane and Epstein conspiracy, unless District Attorney Garrison, now assisted by Lane, produces a miracle. It is not due to incompetence that in the past three years the American newspaper reporters have not been able to discover a scintilla of new evidence to prove a conspiracy. Lane pores hopefully over old photographs only to find that the clues that he thought he had discovered do not exist.

2. In all the three cases it was suggested that important witnesses had been murdered although there was not a tittle of evidence to support this. In the Tichborne case it was the Dowager Lady Tichborne, in the Dreyfus case it was Colonel Sandherr in charge of the Statistical Section, while in Lane's book and articles the number has steadily risen to over 23. It includes Miss Dorothy Kilgallen who was thought to have died from an overdose of sleeping pills in New York City but now seems to have been pursued by the Dallas police.

3. In all the three instances new stories were invented to bolster up a sagging case. Thus the Tichborne claimant told fantastic fables about his visit to South America while in the Dreyfus case Commandant 
Henry produced a forged letter which led to his suicide. In his Playboy interview Lane was asked, "If the President was really killed by a conspiracy, wouldn't the Kennedys be the first to raise a public outcry?" He answered that they did not do so for "a political motive." I do not believe this. Then he said: "Hugh Trevor-Roper (the Oxford history professor) published a major attack on the Warren Commission Report in the London Sunday Times. He told me later he indirectly received a message from Senator Robert Kennedy saying. 'Keep up the good work!" " I do not for a second believe that Senator Kennedy, for whom I have great respect, would have sent such a contemptible secret message. Either Trevor-Roper or Lane must take responsibility for a story that has received wide circulation abroad: as an Oxford man I hope that it is Lane.

4. In all the three cases an attempt to win by blackmail was tried and failed. The Tichborne claimant threatened to destroy the reputation of Kate Tichborne by saying that he had seduced her, but she had the courage to stand up to him. In the Dreyfus Affair every officer in the army was threatened with ruin if he expressed the view that Dreyfus was innocent. Colonel Picquard did so, and as a result his career was destroyed. Lane has now in his Playboy interview threatened President Johnson with political ruin. He has said, "Of course, I don't believe President Johnson had anything to do with the assassinationbut until all the facts are known, I cannot base my disbelief on the evidence. President Johnson has a personal and political stake in dispelling these rumors once and for all." I am certain that this hypocritical warning will not influence the President to appoint a new Commission.

Lane concludes his book with the words: "If the Commission covered itself with shame, it also reflected shame on the Federal Government." He has tried to hold up his country to shame throughout the world. The histories of the Tichborne and of the Dreyfus cases have however shown that sooner or later shame will descend on those who have borne false witness. I am confident that history will repeat itself again. 